Leadership: Jurnal mahasiswa manajemen Pendidikan Islam

ISSN (P): 2721-7108, ISSN (E): 2715-0399

DOI : http://dx.doi.org/10.32478/leadership. v3i1.877

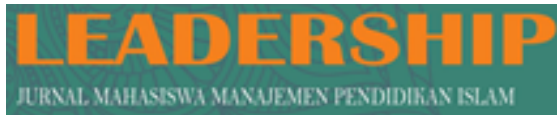

Article Type : Original Research Article

\title{
Manajemen Peserta Didik; Proses Pembelajaran Online Pada Peserta Didik Di Tengah Pandemi Covid-19 Studi Kasus di SMK Terpadu Al-Ishlahiyah Singosari.
}

\author{
Maulida Qurratul Aini \\ STAI Ma'had Aly Al-Hikam Malang, Indonesia
}

Corresponding author: Email: maulidiaanisa297@gmail.com

Submission Track:

Submisson : :03-01-2022

Accept Submission : 04-01-2022

Avaliable Online : :04-01-2022

Copyright @ 2022 Author

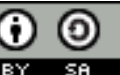

This work is licensed under a Creative Commons Attribution-ShareAlike 4.0

\begin{abstract}
As an educational institution that is superior in terms of religious education and creativity, SMK Terpadu Al-Islahiyah Singosari - Malang, always got praises and awards from various competitions and performances. This things certainly makes proud of all the components that are in SMK Terpadu AlIshlahiyah. But since of corona virus or commonly called covid - 19, the institution of education is predicted is the easiest place for covid - 19 to spread, because of the activities that are always done in groups. This is what makes the interest of the author to investigate this issue further.

The existence of covid - 19 pandemic seems to be a test for educational institutions. All educational institutions in Indonesia is required to be able to keep running the learning process in this pandemic situation. The government decided to do online learning because of this situation. as what SMK Terpadu AlIshlahiyah has done, they are also implementing online learning in this pandemic situation.

This study uses a qualitative method in the form of interviews, in addition, this study also carried out by way of review of the literature to corroborate the explanation of the results of the interview. This is done to determine how the application of management students in the learning process in the middle of the pandemic of covid - 19 in SMK Terpadu Al-Ishlahiyah. As well as the impact or what obstacles are given Covid - 19 to the learning process of learners.
\end{abstract}

Keywords : management of learners, online learning, covid - 19. 
Leadership: Jurnal mahasiswa manajemen pendidikan Islam

ISSN (P): 2721-7108, ISSN (E): 2715-0399

Vol. 03 No. 01 bulan Desember 2021

\begin{abstract}
Abstrak
Sebagai lembaga pendidikan yang unggul dalam segi pendidikan agama dan kreatifitasnya, SMK Terpadu Al-Islahiyah Singosari - Malang, selalu mendapat pujian dan penghargaan-penghargaan dari berbagai macam lomba dan pentas. Hal ini tentu membuat bangga seluruh komponen yang berada di SMK Terpadu Al-Ishlahiyah. Namun sejak merebaknya wabah virus corona atau yang biasa disebut covid - 19, lembaga pendidikan digadang-gadang merupakan tempat yang paling mudah dalam penyebaran covid - 19, dikarenakan aktifitas dan kegiatannya yang selalu dilakukan secara berkerumun atau bersama-sama. Hal ini yang menjadikan ketertarikan penulis untuk meneliti lebih lanjut masalah ini.

adanya pandemi covid - 19 ini tentu saja menjadi sebuah ujian terbesar bagi lembaga pendidikan. Semua lembaga pendidikan di Indonesia dituntut harus bisa tetap menjalankan pembelajaran di masa pandemi saat ini. Hingga pemerintah pun memutuskan untuk melakukan pembelajaran secara online. Begitu pula yang dilakukan oleh SMK Terpadu Al-Ishlahiyah yang juga menerapkan pembelajaran secara online di masa pandemi covid-19 ini.

Penelitian ini menggunakan metode kualitatif yang berupa wawancara, selain itu penelitian ini juga dilakukan dengan cara kajian literatur untuk menguatkan penjelasan hasil wawancara. Hal ini dilakukan untuk mengetahui bagaimana penerapan manajemen peserta didik dalam proses pembelajaran di tengah pandemi covid - 19 di SMK Terpadu Al-Ishlahiyah. Serta dampak atau hambatan apa yang diberikan Covid - 19 terhadap proses pembelajaran peserta didik.
\end{abstract}

Kata Kunci : manajemen peserta didik, pembelajaran online, covid - 19.

\title{
PENDAHULUAN
}

Corona Virus disease atau yang biasa kita kenal dengan Covid-19 membuat keresahan yang luar biasa di berbagai belahan dunia. Virus ini mulai muncul di Indonesia di awal tahun 2020, bahkan virus yang digadang-gadang dapat mematikan ini membuat para pemimpin negara kewalahan dan harus merubah beberapa sistem yang telah mereka tetapkan sebelumnya. Covid - 19 tidak hanya mempengaruhi dari sosial maupun ekonomi, namun hal ini juga berimbas banyak pada tatanan manajemen pendidikan yang ada di Indonesia. Sepert perubahan yang terjadi pada sistem pendidikan di Indonesia yang mengharuskan semua lembaga pendidikan baik sekolah formal maupun non formal, negeri maupun swasta merubah semua sistem manajemen yang ada secara drastis.

Berubahnya sistem pendidikan nasional yang ada tersebut, terjadi baik itu secara manajemen administrasinya ataupun dari segi manajemen pembelajarannya yang ada. Adanya covid - 19 saat ini, secara keadaan memaksa pemerintahan pusat hingga pemerintahan daerah harus menetapkan dan menutuskan suatu kebijakan dengan memberhentikan sementara proses belajar di sekolah ataupun tatap muka untuk sementara 
Vol. xx No. xx bulan xx 20xx

waktu. Sesuai dengan surat edaran nomor 4 tahun 2020 memutuskan proses belajar mengajar harus dilaksanakan dari rumah masing-masing atau yang kerap disebut dengan BDR atau Belajar Dari Rumah ( KEMENDIKBUD 2020). Hal ini tentu saja berlangsung sampai tenggang waktu yang tidak bisa diketahui dan diprediksi oleh semua lembaga pendidikan.

Semakin krisisnya kesehatan yang disebabkan oleh covid-19 ini, semakin banyak kebijakan-kebijakan yang ditetapkan oleh pemerintah, seperti berjaga jarak (physical distancing), pembatasan social (social distancing), memakai masker, selalu cuci tangan, bekerja dari rumah (work from home), bahkan belajar dari rumah dengan metode pembelajaran E-Learning. Tentu saja keadaan ini merugikan banyak pihak tanpa terkecuali.

Adanya kebijakan-kebijakan yang dikeluarkan oleh pemerintah menyebabkan pemberlakuannya proses pembelajaran secara online dari rumah atau secara physical distancing hingga menjadi permasalahan terbesar untuk saat ini, baik dari segi waktu, lokasi dan jarak. ${ }^{1}$ Pemerintah pun tentu saja merasa kesusahan dengan menerapkannya aturanaturan dan kebijakan baru di dunia pendidikan dan hal ini lah yang menjadi tantangan terbesar dalam dunia pendidikan untuk saat ini..

Bagaimana tidak, pemberlakuannya pembelajaran secara online di semua lembaga pendidikan pun juga begitu membebani pengajar, peserta didik dan juga wali murid. Permasalahan seperti ini juga sangat dirasakan disemua lembaga pendidikan, baik itu lembaga pendidik negeri maupun lembaga pendidikan swasta. Lembaga pendidikan di Indonesia pun tak bisa memungkiri bahwa bisa jadi ini kali pertama mereka menerapkannya kegiatan belajar secara online.

Semua lembaga pendidikan swasta maupun negeri dalam melaksanakan pembelajaran secara online pun membutuhkan banyak kesiapan dalam pelaksanakannya. Banyak sekali lembaga pendidikan yang menanyakan mengenai keefektifan dari diberlakukannya pembelajaran secara online tersebut. Bukan hanya itu, banyak juga para pendidik menanyakan metode pembelajaran seperti apa yang harus diterapkan selama pembelajaran online di masa pandemic covid 19 ini.

Banyaknya pertanyaan seperti ini sering muncul berkaitan dengan tidak meratanya fasilitas yang ada di masyarakat, seperti jaringan internet atau bahkan alat penunjang yang digunakan dalam metode pembelajaran online. Kurangnya pelatihan atau pendampingan pada pendidik dalam menggunakan media online pun juga menjadi kendala tersendiri bagi pendidik. Pendidik harus mampu menyampaikan pembelajaran sesuai dengan kebutuhan peserta didik.

Munculnya berbagai pertanyaan mengenai metode pembelajaran online dari mulai kesiapan akan pelaksanaannya, metode seperti apa yang akan digunakan, bahan ajar seperti apa yang akan disampaikan atau yang akan digunakan. Sebab tidak bisa dipungkira, bahwa semua lembaga pendidikan sedang beradaptasi dalam melakukan pembelajaran secara online. Maka dari itu peneliti mengambil judul "Manajemen Peserta Didik; Proses Pembelajaran Online Pada Peserta Didik Di Tengah Pandemi Covid-19 Studi Kasus di SMK

\footnotetext{
${ }^{1}$ Kusuma, J.W., \& Hamidah, 2020, Platfrom Whatsaap Group Dan Webinar Zoom Dalam Pembelajaran Jarak Jauh Pada Masa Pandemi Covid 19, Jurnal Ilmiah Pendidikan Matematika, Vol. 5, No. 1
} 
Leadership: Jurnal mahasiswa manajemen pendidikan Islam

ISSN (P): 2721-7108, ISSN (E): 2715-0399

Vol. 03 No. 01 bulan Desember 2021

Terpadu Al-Ishlahiyah Singosari", guna mengetahui sejauh mana penerapan pembelajaran online ditengah pandemi covid-19 saat ini terutamanya di SMK Terpadu Al-Islahiyah Singosari.

\section{LITERATUR REVIEW}

\section{A. Manajemen Peserta Didik}

\section{Manajemen}

Sejatinya setiap hal yang ada dan yang terjadi pasti membutuhkan manajemen, baik itu dari sebuah instansi, perusahaan, organisasi maupun memanajemen diri sendiri. Intansi, perusahaan maupun organisasi yang mampu berdiri secara baik hingga bisa bertahan lama semua itu tidak lepas dari manajemen yang baik dan benar dalam pengelolaannya. Namun perlu diketahui akan pengertian manajemen yang sesungguhnya agar kita benar-benar paham sebelum melakukan manajamen dalam suatu hal.

Manajemen menurut Etimologi berasal dari bahasa Inggris "management" yang dikembangkan dari kata "manage" ini sendiri berasal dari Italia "manegglo" yang diadopsi dari bahasa latin "managlare" yang berasal dari kata "manus" yang artinya tangan. ${ }^{2}$ Jika istilah administrasi banyak digunakan oleh Amerika serikat, Kanada dan Australia, maka manajemen banyak digunakan oleh Inggris, Afrika dan Negara-negara Eropa lainnya. ${ }^{3}$

Manajemen menurut KBBI (Kamus Besar Bahasa Indonesia) memilki arti sebagai proses pemakaian sumber daya secara efektif untuk mencapai sasaran yang telah ditentukan. ${ }^{4}$ Sedangkan menurut George Terry, manajemen adalah suatu tindakan atau perbuatan seseorang yang berhak menyuruh orang lain mengerjakan sesuatu, sedangkan tanggung jawab tetap di tangan yang menyuruh dengan perencanaan (Planning), pengorganisasian (Organizing), Penggerakan (Actuating), dan pengawasan (Controlling) yang biasa dikenal dengan POAC. ${ }^{5}$

Selanjutnya Andrew Fikun mengatakan manajemen pada umunya berkaitan dengan aktivitas-aktivitas perencanaan, pengorganisasian, pengendalian, penempatan, pengarahan, pemotivasian, komunikasi dan pengambilan keputusan yang dilakukan oleh organisasi dengan tujuan untuk mengkoordinasi sebagai sumber daya yang dimiliki oleh perusahaan sehingga akan dihasilkan produk atau jasa yang efisien ${ }^{6}$ Gibson juga menyatakan bahwa manajemen adalah proses dari seseorang ataupun beberapa individu untuk mengkoordinasi kegiatan- kegiatan dari orang lain untuk memperoleh hasil yang tidak dapat dilakukan seseorang individu saja. ${ }^{7}$

Dari beberapa pendapat para ahli, dapat disimpulkan bahwa manajemen adalah suatu tanggung jawab individu atau kelompok dalam sebuah kegiatan atau

\footnotetext{
${ }^{2}$ Besse Marjani Alwi, dkk, 2018, Manajemen Peserta Didik Pada Taman Pendidikan Anak Usia Dini Doa Ibu, jurnal of early childhood education, vol. 1, no.1

${ }^{3}$ Husaini Usman, Manajemen teori Praktik dan Riset Pendidikan, (Jakarta: PT. Bumi Aksara, 2014),hlm. 5

${ }^{4}$ Pusat Bahasa Departemen Pendidikan Nasional, kamus Bahasa Indonesia, (Jakarta: Pusat Bahasa, 2008), hlm. 919

${ }^{5}$ Elfridawati Mai Dhuhani, 2018, Manajemen Pondok pesantren; Studi Pengelolaan Santri Muallaf di Pondok Pesantren Al-Anshar Ambon, Jurnal Fikratuna, Vol. 9, No. 1

${ }^{6}$ Eka Prihantin, Manajemen Peserta Didik, (Bandung: Alfabet, 2011), hlm. 2

${ }^{7}$ Donni Juni Priansa, Manajemen Peserta Didik dan Model Pembelajaran, (Bandung: Alfabeta, 2015), hlm. 31
} 
Leadership: Jurnal mahasiswa manajemen pendidikan Islam

ISSN (P): 2721-7108, ISSN (E): 2715-0399

Vol. xx No. xx bulan xx 20xx

aktifitas dalam mengatur suatu hal mulai dari perencanaan, pelaksanaan hingga evaluasi.

\section{Peserta Didik}

Peserta didik merupakan gabungan dari dua kata, yaitu peserta dan didik. Biasa disebut juga murid atau pelajar. Penyebutan peserta didik memiliki makna yang sama, yakni orang yang menuntut ilmu atau yang mengikuti kegiatan pendidikan pada suatu lembaga pendidikan. ${ }^{8}$ Banyak sekali pengertian-pengertian tentang peserta didik, salah satunya yaitu undang-undang sistem pendidikan nasional tahun 2003 yang menjelaskan bahwa peserta didik adalah anggota masyarakat yang berusaha mengembangkan potensi diri melalui proses pembelajaran yang tersedia pada jalur, jenjang dan jenis pendidikan tertentu.

Pengertian ini pun diperkuat dengan banyaknya pendapat- pendapat dari para ahli. Menurut Donni Juan Priansa mengungkapkan bahwa peserta didik adalah individu yang membutuhkan untuk berinteraksi dan bersosialisasi dengan lingkungan yang ada disekitarnya, dimana sekolah merupakan salah satu tempat yang formal untuk mendidik dan mengajar peserta didik. ${ }^{9}$

\section{Manajemen Peserta Didik}

Manajemen tentu sudah tidak asing lagi di kalangan masyarakat saat ini, baik itu dalam lingkup terbesar hingga lingkup terkecil sekalipun. Hal ini tentu saja berlaku juga dalam dunia pendidikan. Manajemen yang efektif dan efisien sangatlah dibutuhkan guna menstabilkan keadaan dalam suatu lembaga pendidikan. Hampir semua komponen yang ada dalam dunia pendidikan membutuhkaan manajemen yang efektif dan efisien. Sebab di dalam lembaga pendidikan sendiri pun sangat membutuhkan manajemen mulai dari manajemen peserta didik guna meningkatkan mutu lembaga. Manajemen peserta didik pun merupakan penggabungan dari dua kata, yaitu manajemen dan peserta didik.

Mengutip dari beberapa pendapat para ahli pendidikan tentang manajemen peserta didik, tim dosen Adpen UPI menjelaskan bahwa manajemen peserta didik merupakan upaya untuk memberikan layanan sebaik mungkin kepada peserta didik sejak proses penerimaan sampai saat peserta didik meninggalkan lembaga pendidikan karena sudah lulus atau tamat mengikuti pendidikan pada lembaga pendidikan tersebut. ${ }^{10}$ Menurut Jaja Jahari manajemen peserta didik dapat diartikan sebagai layanan yang mempusatkan perhatian pada pengaturan, pengawasan dan layanan individual seperti pengembangan keseluruhan kemampuan, minat, kebutuhan sampai matang mendapatkan proses pendidikan di sekolah. ${ }^{11}$

Pendapat ini pun diperkuat oleh Mujamil Qomar yang mengatakan bahwa manajemen peserta didik adalah pengelolaan kegiatan yang berkaitan dengan

\footnotetext{
${ }^{8}$ Imam Gunawan, Djum Djum Nor Benty, Manajemen Pendidikan Suatu pengantar Praktik, (Bandung: CV. Alfabeta, 2017), hlm. 133

${ }^{9}$ Donni Juni Priansa, Manajemen Peserta Didik dan Model Pembelajaran, (Bandung: Alfabeta, 2015), hlm. 46

${ }^{10}$ Besse Marjani Alwi, dkk, 2018, Manajemen Peserta Didik Pada Taman Pendidikan Anak Usia Dini Doa Ibu, jurnal of early childhood education, vol. 1, no.1

${ }^{11}$ Jaja Jahari, dkk, 2018, Manajemen Peserta Didik, jurnal islamic education manajemen, vol. 3, no.2
} 
Leadership: Jurnal mahasiswa manajemen pendidikan Islam

ISSN (P): 2721-7108, ISSN (E): 2715-0399

Vol. 03 No. 01 bulan Desember 2021

peserta didik mulai dari awal masuk (bahkan sebelum masuk) bahkan hingga akhir (tamat) dari lembaga pendidikan. ${ }^{12}$ Mulyasa juga menegaskan manajemen peserta didik merupakan pengaturan terhadap kegiatan yang berkaitan dengan peserta didik, mulai dari masuk hingga hingga sampai keluarnya peserta tersebut dari suatu sekolah. ${ }^{13}$

Adapun tujuan dengan adanya manajemen peserta didik di dalam lembaga pendidikan ialah:

a. Meningkatkan pengetahuan, keterampilan dan psikomotorik peserta didik.

b. Menyalurkan dan juga mengembangkan keampuan umum/kecerdasan, bakat dan juga minat peserta didik.

c. Menyalurkan aspirasi, harapan dan memenuhi kebutuhan peserta didik.

d. Peserta didik mencapai kebahagiaan dan kesejahteraan hidup yang lebih lanjut dapat belajar dengan baik dan mencapai cita-cita mereka. ${ }^{14}$

Selain tujuan ada pula pendekatan-pendekatan yang harus digunakan dalam memanajemen peserta didik. Adapun 2 pendekatan dalam manajemen peserta didik diantaranya: ${ }^{15}$

1. Pendekatan kuantitatif

Pendekatan ini lebih menitik beratkan pada segi-segi administrasif dan birokratik lembaga pendidikan. Dalam pendekatan ini diharapkan peserta didik dapat memenuhi tuntutan-tuntutan dan harapan-harapan lembaga pendidikan ditempat peserta didik tersebut berada.

2. Pendekatan kualitatif

Pendekatan ini lebih memberikan perhatian pada kesejahteraan peserta didik.

Dari banyaknya pendapat dari para ahli tentang manajemen peserta didik, dari sini dapat disimpulkan bahwa manajemen peserta didik adalah sebuah usaha lembaga pendidikan yang melibatkan seluruh komponen sekolah dalam pengaturan, pengawasan dan pelayanan pada peserta didik mulai dari awal masuk sekolah hingga keluarnya/tamatnya peserta didik dari sekolah. Hal ini dilakukan guna menciptakan peserta didik yang unggul yang sesuai dengan visi misi lembaga tersebut.

\section{B. Pandemi Covid - 19}

Covid - 19 atau saat ini yang biasa kita sebut dengan corona virus disease awalnya bernama 2019 novel coronavirus (2019-nCoV), kemudian WHO mengumumkan

\footnotetext{
${ }^{12}$ Mujamil Qomar, Manajemen Pendidikan Islam: Strategi Baru Pengelolaan Lembaga Pendidikan Islam, (Jakarta: Erlangga,2007), hlm. 141

13 Mulyasa, Manajemen Berbasis Sekolah Konsep, Strategi, Implementasi, (Bandung: PT. Remaja Rosdakarya, 2003), hlm. 46

${ }^{14}$ Badrudin, Manajemen Peserta Didik, (Jakarta: PT. Indeks, 2014), hlm.

${ }^{15}$ Besse Marjani Alwi, dkk, 2018, Manajemen Peserta Didik Pada Taman Pendidikan Anak Usia Dini

Doa Ibu, jurnal of early childhood education, vol. 1, no.1
} 
Vol. xx No. xx bulan xx 20xx

nama baru dari virus ini pada tanggal 11 Februari $2020^{16}$. Corona Virus Disiase atau yang biasa disingkat covid - 19 merupakan sebuah penyakit menular yang pertama kalu muncul di Wuhan, Ibukota Provinsi Hubei, China sekitar akhir tahun 2019.

Sudah banyak riset dan penelitian yang dilakukan untuk mengenal lebih dalam apa itu virus corona atau covid-19, terutama dalam dunia kesehatan. Namun dalam penelitian dari segi agama, terutama agama Islam belum banyak orang yang melakukan penelitian tentang covid-19. Sejauh ini penyakit yang berbahaya dan menular memang sudah ada sejak jaman Rosulullah, yang disebut dengan Tho'un. Namun perlu diketahui bahwa covid-19 tidak bisa disamakan dengan penyakit tho'un yang ada pada jaman Rosulullah. Sebab secara spesifik covid-19 berbeda dengan tho'un, akan tetapi kita tidak bisa meremehkan, karena covid-19 dan Tho'un sama-sama berbahaya.

Berbahayanya covid-19 mampu menyebar dengan cepat dan hal ini hamper terjadi di seluruh dunia dan menimbulkan dampak yang sangat besar. Sebelumnya covid-19 merupakan virus yang menyebar dan berkembang biak dalam tubuh hewan seperti babi ataupun kuda. Pada akhirnya terdapat beberapa hewan seperti tikus ataupun kelelawar yang menjadi penyebab virus tersebut bisa menular dan berkembang biak pada tubuh manusia ${ }^{17}$.

\section{Konsep Pembelajaran Online}

Dalam metode pembelajaran daring, pendidik dan peserta didik melakukan kegiatan belajar - mengajar secara online dengan memanfaatkan berbagai macam aplikasi yang telah disediakan seperti aplikasi Ruang Guru, Quipper, Google Classroom, atau bahkan berbagai macam aplikasi yang memungkinkan pendidik dan peserta didik melakukan tatap muka seperti Zoom ataupun Google Meet. Selain itu metode pembelajaran online juga bisa disebut dengan metode pembelajaran yang dapat dilakukan dalam konteks ruang dan waktu yang tidak memiliki batasan. ${ }^{18}$

\section{METODE PENELITIAN}

Penelitian ini disusun dengan cara pengumpulan data melalui teknik wawancara dimana teknik wawancara ini masuk kedalam kategori metode penelitian kualitatif. Pengertian dari metode penelitian kualitatif sendiri ialah jenis penelitian yang tidak berkaitan dengan teknik hitung-menghitung yang biasanya dilakukan dengan metode observasi ataupun wawancara dengan objek yang terbatas atau spesifik sehingga data yang diperoleh bisa dikaji secara mendalam oleh penulis ${ }^{19}$.

\footnotetext{
${ }^{16}$ Adityo Susilo, dkk, 2020, Coronavirus Disease 2019: Tinjauan Literature Terkini, jurnal penyakit dalam Indonesia, Vol. 7, no. 1, hlm;45

${ }^{17}$ Yuliana, 2020, Corona Virus Disiases (Covid-19); Sebuah Tinjauan Literatur, Jurnal Wellness and Healthy Magazine, Vol. 2, No. 1, Hlm: 188-189

${ }^{18}$ Dheru Alam perkasa, Eki Saputra, dan Mona Fronita, Sistem Ujian Online Essay dengan penilaian Menggunakan Metode Latent Sematic Analysis (LSA), Jurnal Rekayasa dan manajemen Sistem Informasi, Vol. 1, No.1

${ }^{19}$ Anslem Strauss, Dasar-Dasar Penelitian Kualitatif Tata Langkah dan Teknik-Teknik Teoritis Data, (Yogyakarta: Pustaka pelajar, 2013), hlm. 4
} 
Pada metode wawancara ini peneliti mengikut sertakan beberapa pendidik yang ada di SMK Terpadu Al-Islahiyah Singosari diantara kepala sekolah, bagian tata usaha, dan guru wali kelas 11 OTKP 2, untuk mengetahui sejauh mana perubahan pada manajemen peserta didik terkait proses pembelajaran di masa pandemi covid-19 saat ini. Peneliti juga melakukan kajian literatur untuk memperdalam pengetahuan serta menguatkan teori-teori yang ada. Selain itu peneliti juga melakukan kajian literatur untuk menguatkan pendapat-pendapat yang telah disampaikan oleh pihak yang diwawancara.

\section{HASIL PENELITIAN}

\section{A. Gambaran Umum SMK Terpadu Al-Islahiyah Singosari}

SMK Terpadu Al-Islahiyah Singosari didirikan pada tanggal 05 Mei 2005 oleh Yayasan Pondok Pesantren Al-Islahiyah bersama SMK Negeri Singosari. Pada awal berdirinya SMK Terpadu Al-Islahiyah, sekolah ini merupakan kelas jauh dari SMK Negeri Singosari di Pesantren Al-Islahiyah, yang artinya peserta didik di SMK Terpadu AlIslahiyah secara otomatis juga menjadi peserta didik di SMK Negeri Singosari. Diresmikan oleh Menteri Pendidikan Nasional pada tanggal 25 September 2005 dan disaksikan oleh Kepala Dinas Pendidikan dan Kebudayaan Kabupaten Malang.

Pada usianya yang relatif muda, SMK Terpadu Al-Islahiyah secara terus menerus melakukan usaha perbaikan dan pengembangan dalam rangka dan tujuan menciptakannya lembaga pendidikan yang bermutu. Sesuai dengan namanya (SMK Terpadu Al-Islahiyah), sekolah ini adalah SMK yang terpadu dengan pesantren AlIslahiyah, disamping terpadu dari segi lokasinya (berada di dalam lingkungan pesantren) juga terpadu kurikulumnya, yang mana selain mendapatkan materi SMK, peserta didik juga mendapatkan materi pendidikan pesantren.

Adanya perpaduan antara kurikulum nasional dan kurikulum pesantren diharapkannya dapat mewujudkan integrasi antara akal dan iman. Para lulusan SMK Terpadu Al-Islahiyah disamping memiliki kemampuan professional dalam bidang teknologi informasi dan tata busana, lulusan diharapkan juga memiliki kemampuan agama yang mumpuni dan berbudi pekerti luhur. Sehingga dapat memberikan citra yang baik terhadap masyarakat akan SMK Terpadu Al-Islahiyah.

\section{Profil SMK Terpadu Al-Islahiyah Singosari}

\begin{tabular}{|c|c|}
\hline Nama sekolah & : SMK TERPADU AL-ISLAHIYAH \\
\hline Kelompok & : Swasta \\
\hline NSS & : 322051805052 \\
\hline NPSN & : 20549523 \\
\hline Penyelenggara & : Yayasan Pondok Pesantren Al-Islahiyah \\
\hline Alamat Sekolah & : Jl. Kramat 81, Kec. Singosari \\
\hline Kabupaten : Ma & \\
\hline Website & : http://www.smk-islahiyah.sch,id \\
\hline Email & : smk.islahiyah@gmail.co.id \\
\hline Program Studi/ & npetensi Keahlian \\
\hline & a. Teknik Komputer dan Jaringan (TKJ) \\
\hline & b. Multimedia \\
\hline & c. Busana Butik \\
\hline & d. Administrasi Perkantoran \\
\hline
\end{tabular}


Leadership: Jurnal mahasiswa manajemen pendidikan Islam

ISSN (P): 2721-7108, ISSN (E): 2715-0399

Vol. xx No. xx bulan xx 20xx

\section{Visi dan Misi SMK Terpadu Al-Islahiyah Singosari}

VISI:

Terwujudnya SMK yang unggul dan relevan menuju terbentuknya manusia Indonesia yang memiliki kecerdasan spiritual, intelektual, emosional dan nilai-nilai profesionalisme.

MISI:

a. Mewujudkan integrasi pendidikan pesantren dan kejuruan.

b. Mewujudkan proses pembelajaran yang berkualitas dan menyenangkan berbasis tekonlogi dan kearifan masyarakat local.

c. Mewujudkan lulusan SMK yang memiliki kompetensi yang tinggi dalam bidang ilmu yang didasri akhlakul karima.

d. Mewujudkan sekolah sebagai agen perubahan sosial bagi masyarakat sekitar melalui integrasi teknologi informasi dlam kehidupan masyarakat.

e. Mewujudkan system dan jaringan kerja yang kondusif dengan stakeholder dan pengembangan masyarakat yang lain.

\section{Struktur Organisasi SMK Terpadu Al-Islahiyah Singosari}

SMK Terpadu Al-Islahiyah Merupakan SMK Terpadu yang masih berada dan dikelola oleh lingkup pesantren Al-Islahiyah. Adapun system organisadi di SMK Terpadu Al-Islahiyah Singosari terdiri dari: ${ }^{20}$

a. Ketua Yayasan : Dra. Hj. Anisah Mahfudz, M.Ap

b. Kepala Sekolah : Muhammad Nashrulloh, S.Pd

c. Bendahara : Shofa Qonita, S.HI

d. Kepala Tata Usaha: Domet, S.Pd.I

e. Waka Kurikulum : Hermanto, S.Pd

f. Waka kesiswaan : Laili Uswatun Hasanah, S.Psi

g. Waka Sarpras : H. Rudik Setiawan, S.Si, M.Agr

h. Waka Humas : Ahsani Fathur Rohman

i. Kepala Program Keahlian:

- Teknik Komputer Jaringan : hermanto, S.Pd

- Multimedia : Ahmad Fajar Azmil Mustaqor, S.Sn

- Busana Butik : Nailul Zakiyyatil Ngirganillah, S.Pd

- Administrasi Perkantoran : Choirul Fathoni, S.Pd

\section{B. Manajemen Pada Pembelajaran Peserta Didik}

SMK Terpadu Al-Islahiyah, awal mulanya merupakan kelas jauh dari SMK Negeri Singosari yang berada di Pesantren Al-Islahiyah. Artinya peserta didik di SMK Terpadu Al-Islahiyah secara otomatis juga menjadi peserta didik di SMK Negeri

${ }^{20}$ Tabel dapat dilihat dilampiran. 
Singosari. Dikarenakan peserta didiknya banyak dari wilayah sektar pesantren AlIslahiyah dan ingin mengelola lembaga sesuai dengan visi misi pesantren akhirnya SMK Terpadu Al-Islahiyah berdiri sendiri dan diresmikan oleh Menteri Pendidikan Nasional yang disaksikan oleh Kepala Dinas Pendidikan dan Kebudayaan Kabupaten Malang.

Sistem manajemen pembelajaran Di SMK Terpadu Al-Islahiyah Singosari menggunakan sistem yang sama seperti yang diterapkan oleh lembaga formal lainnya, dengan menggunakan pedoman-pedoman manajerial yang ditetapkan oleh pemerintah. SMK Terpadu Al-Islahiyah merupakan lembaga pendidikan yang masih berada di kawasan pesantren, maka sistem manajemennya tentu saja dikombinasi dengan pesantren. Hal ini lah yang memberikan corak berbeda pada SMK Terpadu AlIslahiyah.

Memberikan corak yang berbeda, SMK Terpadu Al-Islahiyah dalam setiap tahunnya selalu mengalami peningkatan terutama dari segi pesera didiknya. Hal ini berbanding lurus dengan hasil wawancara yang disampaikan oleh bapak Domet, S.Pd.I selaku kepala TU di SMK Terpadu Al-Islahiyah, yang menjadi narasumber 1 dalam penelitian ini. Beliau mengatakan bahwa selama kurang lebih 3 tahun belakang ini, jumlah peserta didik selalu mengalami peningkatan. Penyampaiannya pun diperkuat dengan data-data yang ditunjukan kepada peneliti.

Pembelajaran di SMK Terpadu Al-Islahiyah Singosari berlandaskan pada pesantren Al-Islahiyah. Pembelajaran yang digunakan merupakan kombinasi antara kurikulum SMK dan kurikulum pesantren. Tujuannya ialah agar bisa melahirkan pemuda-pemudi yang berkompetensi baik dari segi kejuruan dan segi agama. Tidak sedikit pula penghargaan dan prestasi yang diraih oleh peserta didik di SMK AL-Islahiyah dalam bidang keagamaan.

Dalam mengatur peserta didik di SMK Al-Islahiyah, selalu dilakukan secara tertib dan runtut. Hal ini dapat dilihat dari jadwal kegiatan harian yang disampaikan oleh narasumber $1 .^{21}$ Adapun jadwal kegiatan di SMK Terpadu Al-Islahiyah sebagai berikut:

Tabel 4.1 jadwal kegiatan peserta didik sebelum pandemi

Jam ke-

Keterangan waktu

$06.45-07.40$

$07.40-08.20$

$08.20-09.00$

$09.00-09.40$

$09.40-10.10$

\section{Keterangan kegiatan}

Kegiatan keagamaan (sholat duha)

Kegiatan KBM jam ke- 1

Kegiatan KBM jam ke- 2

Kegiatan KBM jam ke- 3

istirahat

${ }^{21}$ Narasumber 1: Pak domest, S.Pd.I 
Leadership: Jurnal mahasiswa manajemen pendidikan Islam

ISSN (P): 2721-7108, ISSN (E): 2715-0399

Vol. xx No. xx bulan xx 20xx

$\begin{array}{lll}\text { 5. } & 10.10-10.50 & \text { Kegiatan KBM jam ke- } 4 \\ \text { 6. } & 10.50-11.30 & \text { Kegiatan KBM jam ke- } 5 \\ - & 11.30-12.15 & \text { Kegiatan keagamaan (sholat duhur) } \\ \text { 7. } & 12.15-12.55 & \text { Kegiatan KBM jam ke- } 6 \\ 8 . & 12.55-13.35 & \text { Kegiatan KBM jam ke- 7 }\end{array}$

9.

10.

Diniyah

\section{Pembelajaran Online Pada Peserta Didik Di Tengah Pandemi Covid-19}

Wabah covid - 19 merupakan jenis wabah yang tingkat penyebarannya dan penularannya sangat tinggi dan cepat. Berbagai upaya telah dilakukan untuk meminimalisir dan menekan mata rantai penyebaran covid - 19 ini. Kepala sekolah SMK Terpadu Al-Islahiyah selaku narasumber 2 Bapak Muhammad Nashrulloh, S.Pd mengatakan bahwa, adanya pandemi covid - 19 ini tentu saja menjadi sebuah ujian terbesar bagi lembaga pendidikan. Semua lembaga pendidikan di Indonesia dituntut harus bisa tetap menjalankan pembelajaran di masa pandemi saat ini. Hingga pemerintah pun memutuskan untuk melakukan pembelajaran secara online.

Pendapat ini pun dipertegas oleh menteri pendidikan yaitu Nadiem Makarim yang mengatakan bahwa pembelajaran online merupakan alternatif terbaik untuk meningkatkan kompetensi pendidik dan peserta didik untuk lebih mandiri, kreatif dan inovatif ${ }^{22}$. Sudah banyak SK yang diturunkan oleh dinas pendidikan setempat bahwa pembelajaran peserta didik harus dilaksanakan secara online atau daring (dalam jaringan). Akan tetapi tidak semua mata pelajaran bisa dilakukan secara online atau daring.

Sebagai lembaga pendidikan tingkat kejuruan, SMK Terpadu Al-Islahiyah akhirnya menerapkan Luring (luar jaringan) dengan berbagai banyak pertimbangan, yang mana peserta didik dapat masuk sekolah namun sesuai dengan ketentuan lembaga tersebut. Adapun jadwal kegiatan di SMK Terpadu Al-Islahiyah Singosari selama pandemi yaitu:

\section{2 jadwal tabel kegiatan peserta didik selama pandemi}

Jam ke- Keterangan waktu

1.

$2 . \quad 07.40-08.15$
Keterangan kegiatan

Kegiatan keagamaan (sholat duha)

Kegiatan KBM jam ke- 1

22 https://youtu.be/KbROBdJSv74 
Leadership: Jurnal mahasiswa manajemen pendidikan Islam

ISSN (P): 2721-7108, ISSN (E): 2715-0399

Vol. 03 No. 01 bulan Desember 2021

$\begin{array}{rrr}\text { 3. } & 08.15-08.50 & \text { Kegiatan KBM jam ke- 2 } \\ \text { 4. } & 08.50-09.25 & \text { Kegiatan KBM jam ke- 3 } \\ - & 09.25-09.55 & \text { Istirahat } \\ 5 . & 09.55-10.30 & \text { Kegiatan KBM jam ke- 4 } \\ \text { 6. } & 10.30-11.05 & \text { Kegiatan KBM jam ke- } 5 \\ \text { 7. } & 11.05-11.35 & \text { Kegiatan KBM jam ke- 6 } \\ \text { 8. } & 13.35-14.05 & \text { Kegiatan KBM jam ke- 7 }\end{array}$

Perlu diketahui bahwa selama adanya luring, tidak semua peserta didik dapat pergi ke sekolah. Peserta didik yang akan melakukan luring harus ke sekolah sesuai dengan jadwal yang telah ditetapkan. Berikut ini merupakan jadwal luring dan daring dari setiap kelas yang telah disusun oleh para guru:

Tabel 4.3 luring dan daring dari setiap kelas

Kelas

\begin{tabular}{|c|c|c|c|}
\hline Hari & $x$ & $\mathbf{X I}$ & XII \\
\hline Senin & Luring (tatap muka) & $\begin{array}{l}\text { Daring (belajar dari } \\
\text { rumah) }\end{array}$ & $\begin{array}{l}\text { Daring (belajar dari } \\
\text { rumah) }\end{array}$ \\
\hline Selasa & Luring (tatap muka) & $\begin{array}{l}\text { Daring (belajar dari } \\
\text { rumah) }\end{array}$ & $\begin{array}{l}\text { Daring (belajar dari } \\
\text { rumah) }\end{array}$ \\
\hline Rabu & $\begin{array}{l}\text { Daring (belajar dari } \\
\text { rumah) }\end{array}$ & Luring (tatap muka) & $\begin{array}{l}\text { Daring (belajar dari } \\
\text { rumah) }\end{array}$ \\
\hline Kamis & $\begin{array}{l}\text { Daring (belajar dari } \\
\text { rumah) }\end{array}$ & Luring (tatap muka) & $\begin{array}{l}\text { Daring (belajar dari } \\
\text { rumah) }\end{array}$ \\
\hline Jumat & $\begin{array}{l}\text { Daring (belajar dari } \\
\text { rumah) }\end{array}$ & $\begin{array}{l}\text { Daring (belajar dari } \\
\text { rumah) }\end{array}$ & Luring (tatap muka) \\
\hline Sabtu & $\begin{array}{l}\text { Daring (belajar dari } \\
\text { rumah) }\end{array}$ & $\begin{array}{l}\text { Daring (belajar dari } \\
\text { rumah) }\end{array}$ & Luring (tatap muka) \\
\hline
\end{tabular}

\section{PEMBAHASAN}

A. Manajemen Pada Pembelajaran Peserta Didik

Sebagai lembaga pendidikan yang unggul dalam segi pendidikan agama dan kreatifitasnya, SMK Terpadu Al-Islahiyah selalu mendapat pujian dan penghargaan- 
penghargaan dari berbagai macam lomba. Salah satu penghargaan yang perna diraih ialah kejuaraan tingkat nasional yaitu juara 1 lomba film fiksi. ${ }^{23}$ Banyak sekali karyakarya yang dihasilkan oleh peserta didik SMK Terpadu Al-Ishlahiyah, dan semua karya tersebut mengandung unsur dakwah sesuai dengan visi misi lembaga.

Tentu saja banyak masyarakat yang mengapresiasi atas perkembangan SMK Terpadu Al-Ishlahiyah. Walaupun baru berdiri pada tahun 2005, lembaga pendidikan ini mampu bersaing baik dengan lembaga-lembaga pendidikan swasta mauapun negeri lainnya. Hal ini tentu dapat terjadi sebab adanya manajemen yang baik dalam lembaga pendidikan tersebut, terutama dalam segi pembelajaran yang diberikan pada peserta didik.

SMK Terpadu Al-Ishlahiyah selalu melakukan inovasi dalam setiap tahunnya. Hal ini dapat dilihat pada kegiatan peserta didik di sekolah, mereka tidak hanya diajarkan pendidikan moral akan tetapi juga pendidikan spiritual. Adanya kegiatan pembelajaran agama inti ataupun tambahan seperti diniyah dan banjari selalu melakukan inovasi dan pengembangan.

Tentu saja jika dalam melakukan inovasi dan pengembangan pembelajaran yang ada, pasti ada hambatan dan kendala yang dihadapi di dalamnya. Hal ini ditunjang oleh pendapat Bu Laili uswatun Hasanah, S.Psi atau yang biasa dipanggil Bu Ana, yang merupakan Wakil Kepala Kesiswaan selaku narasumber 3. Beliau mengatakan bahwa dalam melakukan pengembangan terutama dalam segi pembelajaran tentu saja banyak hambatan dan kendala yang dihadapi.

Beliau juga mengatakan bahwa kendala yang cukup berat dihadapi adalah para peserta didik itu sendiri. Diusia peserta didik yang kisaran 15-18 tahun mereka sejatinya sudah mampu menentukan, akan tetapi lembaga pendidikan ditempat mereka belajar sudah memiliki aturan dan ketetapan yang ada. Hal ini lah yang sering dirasakan oleh para pendidik dalam memanajemen peeserta didik, namun kendala ini dapat dihadapi dengan menerapkan prinsip manajemen yang baik.

Sesuai dengan teori prinsip manajemen pada umumnya, SMK Terpadu AlIshlahiyah juga menerapkan prinsip manajemen, diantaranya perencanaan, pengorganisasian, pelaksanaan dan evaluasi. Setiap pendidik mempunyai cara sendiri dalam mengelola dan memanajemen peserta didik. Sesuai dengan yang ada di lapangan, para pendidik mempunyai ciri khas tersendiri dalam memanajemen peserta didik dalam pembelajaran.

\section{B. Pembelajaran Online Pada Peserta Didik Di Tengah Pandemi Covid-19}

Sebagai peserta didik yang terbiasa belajar dengan sistem tatap muka, pemberlakuan belajar daring atau secara online dari rumah semenjak masa pandemi covid - 19 tentu menimbulkan banyak problematika. Bagaimana tidak, semenjak pembelajaran dilakukan secara daring banyak pelajaran yang tidak terlaksana dengan baik. SMK Terpadu Al-Ishlahiyah merupakan sekolah menengah kejuruan yang mana hampir kebanyakan mata pelajaran yang ada selalu membutuhkan praktek langsung dan diawasi oleh guru mata pelajaran tersebut.

Sebagai lembaga pendidikan yang taat akan peraturan dinas pendidikan, SMK Terpadu Al-Ishlahiyah juga menerapkan pembelajaran secara daring selama pandemi

${ }^{23}$ https://www.smk-ishlahiyah.sch.id 
covid - 19 ini. Demi untuk mempertahankan kualitas dan kuantitas lembaga pendidikan, pendidik dan para staff lainnya dituntut untuk dapat melakukan inovasi dalam pembelajaran online di masa pandemi saat ini. Para pendidik SMK Terpadu Al-Ishlahiyah pun selalu memantau perkembangan peserta didik walau secara online, baik itu dari segi pembelajaran maupun dari segi moral dan agama.

Pemantauan perkembangan peserta didik dapat terlaksana dengan baik. Hal ini disampaikan oleh Bu Sari Damayanti selaku narasumber 4 yaitu wali kelas XI OTKP 2, beliau mengatakan bahwa selama pandemi sistem pembelajaran murid-murid berjalan dengan lancar walaupun harus dilakukan secara online. Akan tetapi seiring berjalannya waktu, tingkat kebosanan dan kejenuhan peserta didik sudah mulai terlihat. Pendidik lainnya pun menyayangkan jika pembelajaran dilakukan secara online terus-menerus, hal ini tentu saja akan berpengaruh pada hasil belajar yang berbeda saat sebelum pandemi.

Tidak sedikit problematika yang dihadapi peserta didik dalam pelaksanaan pembelajaran online ini. Hal ini dapat diketahui seperti tidak adanya akses internet, buruknya sinyal internet, jam belajar yang tidak sesuai dengan waktunya, dan minimnnya sarana dan prasarana yang dimiliki guna menunjang pembelajaran online. Tentu ini menjadi kendala dan hambatan baik dari pendidik maupun peserta didik.

Seiring iring berjalannya waktu dan sesuai dengan kebijakan dinas pendidikan setempat, SMK Terpadu Al-Ishlahiyah dapat melakukan pembelajaran secara luring atau secara tatap muka. Hal ini pun dibenarkan oleh narasumber $2 .{ }^{24}$ Akan tetapi, luring dilakukan untuk mata pelajaran yang mewajibkan peserta didik untuk praktek dan diawasi oleh guru mata pelajaran tersebut. Pelaksanaan luring pun diatur sedemikian baik sesuai dengan peraturan dari dinas pendidikan setempat dan sesuai dengan protokol kesehatan yang telah ditetapkan.

\section{PENUTUP}

Manajemen peserta didik dalam proses pembelajaran online pada peserta didik di tengah pandemi covid-19 tentu saja tidak terus berjalan dengan baik. Pasti ada kendalakendala yang dihadapi dalam proses pembelajaran online, begitu pula yang dialami oleh SMK Terpadu Al-Ishlahiyah. Adanya pandemi covid - 19 ini tentu saja menjadi sebuah ujian terbesar bagi lembaga pendidikan. Semua lembaga pendidikan di Indonesia dituntut harus bisa tetap menjalankan pembelajaran di masa pandemi saat ini.

Sebagai lembaga pendidikan tingkat kejuruan, SMK Terpadu Al-Ishlahiyah akhirnya menerapkan Luring (luar jaringan) dengan berbagai banyak pertimbangan, yang mana peserta didik dapat masuk sekolah namun sesuai dengan ketentuan lembaga tersebut. Luring dilakukan untuk mata pelajaran yang mewajibkan peserta didik untuk praktek dan diawasi oleh guru mata pelajaran tersebut. Pelaksanaan luring pun diatur sedemikian baik sesuai dengan peraturan dari dinas pendidikan setempat dan sesuai dengan protokol kesehatan yang telah ditetapkan

\footnotetext{
${ }^{24}$ Narasumber 2: Muhammad Nashrulloh, S.Pd
} 
Leadership: Jurnal mahasiswa manajemen pendidikan Islam

ISSN (P): 2721-7108, ISSN (E): 2715-0399

Vol. xx No. xx bulan xx 20xx

\section{DAFTAR PUSTAKA}

Kusuma, J.W., \& Hamidah, 2020, Platfrom Whatsaap Group Dan Webinar Zoom Dalam Pembelajaran Jarak Jauh Pada Masa Pandemi Covid 19, Jurnal IImiah Pendidikan Matematika, Vol. 5, No. 1

Alwi, Besse Marjani. dkk, 2018 “Manajemen Peserta Didik Pada Taman Pendidikan Anak Usia Dini Doa Ibu". jurnal of early childhood education. vol. 1. no.1

Usman, Husaini. 2014. Manajemen teori Praktik dan Riset Pendidikan. Jakarta: PT. Bumi Aksara.

Pusat Bahasa Departemen Pendidikan Nasional. 2008. kamus Bahasa Indonesia. Jakarta: Pusat Bahasa.

Dhuhani, Elfridawati Mai. 2018. "Manajemen Pondok pesantren; Studi Pengelolaan Santri Muallaf di Pondok Pesantren Al-Anshar Ambon". Jurnal Fikratuna, Vol. 9. No. 1 Prihantin, Eka. 2011. Manajemen Peserta Didik. Bandung: Alfabet.

Priansa, Donni Juni. 2015. Manajemen Peserta Didik dan Model Pembelajaran. Bandung: Alfabeta.

Gunawan, Imam. Djum Djum Nor Benty. 2017. Manajemen Pendidikan Suatu pengantar Praktik. Bandung: CV. Alfabeta Jahari, Jaja. Dkk. 2018. "Manajemen Peserta Didik". jurnal islamic education manajemen. vol. 3. no.2

Qomar, Mujamil. 2007. Manajemen Pendidikan Islam: Strategi Baru Pengelolaan Lembaga Pendidikan Islam. Jakarta: Erlangga.

Mulyasa. 2003. Manajemen Berbasis Sekolah Konsep, Strategi, Implementasi. Bandung: PT. Remaja Rosdakarya.

Badrudin. 2014. Manajemen Peserta Didik. Jakarta: PT. Indeks.

Susilo, Adityo. dkk, 2020 "Coronavirus Disease 2019: Tinjauan Literature Terkini”. jurnal penyakit dalam Indonesia. Vol. 7. no. 1

Yuliana. 2020." Corona Virus Disiases (Covid-19); Sebuah Tinjauan Literatur." Jurnal Wellness and Healthy Magazine, Vol. 2, No. 1

Perkasa, Dheru Alam. Dkk. "Sistem Ujian Online Essay dengan penilaian Menggunakan Metode Latent Sematic Analysis (LSA)". Jurnal Rekayasa dan manajemen Sistem Informasi. Vol. 1. No.1

Strauss, Anslem. 2013. Dasar-Dasar Penelitian Kualitatif Tata Langkah dan TeknikTeknik Teoritis Data. Yogyakarta: Pustaka pelajar.

https://youtu.be/KbROBdJSv74

https://www.smk-ishlahiyah.sch.id 